УДК 111

DOI: $10.18384 / 2310-7227-2015-4-15-20$

\title{
Захарова О.B.
}

Тюменский государственный университет

\section{СОДЕРЖАТЕЛЬНАЯ СТОРОНА ЛЮБОВАНИЯ ПРИРОДОЙ}

Аннотация. Статья продолжает исследование эстетического любования природой, выполняемое в рамках эстетической антропологии. Предложенный подход к восприятию природы через любование ею способен стать основой неутилитарного отношения к природе и способствовать решению экологических проблем. В данной статье рассматривается содержательная сторона любования природой; осуществляется попытка ответа на вопрос, чем любуется человек, воспринимая природу. Ответ на вопрос связывается с открытием различных аспектов совершенства природы.

Ключевые слова: любование природой, эстетическое восприятие, решение экологических проблем.

\section{Zakharova \\ Tyumen State University}

\section{THE MEANING OF ADMIRING NATURE}

Abstract. The article continues to explore the aesthetic admiration of nature performed within the framework of Esthetic anthropology. The proposed approach to the perception of nature by admiring it can become the basis of non-utilitarian attitude towards nature and help solve environmental problems. This article discusses the meaning of admiring nature and makes an attempt to answer the question: what man admires perceiving nature? The answer to the question is associated with the discovery of various aspects of the perfection of nature.

Key words: admiring nature, aesthetic perception, the solution of environmental problems.

Нерешённость современных экологических проблем заставляет искать новые способы преодоления антропоцентризма в отношении к природе. Естественная среда обитания, частью которой является человек, должна стать для него особой ценностью. Для формирования подобного мировоззрения мы предлагаем использовать опыт эстетического восприятия природы.

Рассматривая формальную сторону эстетического восприятия природы, мы определяем возможности диалога применительно к данной проблеме. При этом мы опираемся на работы М.М. Бахтина, М. Бубера, А. Швейцера, К. Лоренца, Н.А. Бердяева, М.Н. Щербинина, И.Б. Муравьева. В рамках эстетической антропологии $[18 ; 6]$ нами отмечено, что любовь к природе в соединении с процессом эстетического восприятия природы способна дать новый синтез, уже имеющий выражение в языке.

(C) Захарова O.B., 2015. 
В русском языке процесс восхищения чем-либо обозначается словом «любование». На наш взгляд, это слово соединяет в себе интенциональность, созерцательность восприятия и чувственность, оценочность любви. Оно происходит от глагола любоваться 'смотреть на кого-то или на что-то с удовольствием' [16, с. 274]. В «Новом словаре русского языка (толково-словообразовательном)» Т.Ф. Ефремовой слово «любоваться» имеет два значения: «1. Рассматривать, созерцать коголибо, что-либо, получая эстетическое удовольствие; 2. Испытывать удовлетворение, восхищение при взгляде на кого-либо, что-либо, наблюдая за кемлибо, чем-либо» [5]. В русских сказках появилось слово «любо», которое использовалось в значении 'приятно, хорошо' От него и произошёл глагол «любоваться» и существительное «любование». И это подтверждает, что в самом происхождении слова заложен аксиологический аспект: любуюсь тем, что хорошо, приятно, иенно для меня, нравится мне. К. Льюис называет такое чувство «любовь-оценка». Мы просто дивимся чуду, даже если оно не для нас. Например, восхищаемся садом, потому что чувствуем, что он по праву это заслужил и будет бессовестно не порадоваться ему [8].

Если любование является формой эстетического восприятия природы, то возникает вопрос о том, что является его содержанием. В данной статье предлагаем рассмотреть в качестве такого содержания совершенство природы. Совершенство будем понимать как высшую степень, предел какоголибо положительного качества. Человек любуется, испытывает восхищение при восприятии совершенства при- родного мира. На наш взгляд, можно выделить некоторые аспекты любования природой как совершенством.

\section{Совершенное творение божества}

В той или иной степени восхищение природным миром характерно в различной степени для представителей многих религий. Оно обостряется в периоды господства религиозного мировоззрения. Однако, далеко не повсеместно и, по-видимому, не во всех религиях. Так, ряд известных культурологов и экологов (Л. Уайт, Р. Нэш, Н.Н. Моисеев и др.) выдвинули обвинения в адрес христианства, считая, что в Библии содержится идеи о несамостоятельности природы, её зависимости от Творца, о превосходстве духовного над материальным, о грехопадении, омрачившем первоначально совершенное творение.

Однако следует отметить, что в Священном Писании мы можем обнаружить много слов, воспевающих красоту и значимость природного мира. В христианстве напоминанием о воплощении и искуплении Христа служит обряд евхаристии. Его чувственные, эмоционально-эстетические стороны, согласно христианскому учению, содействует освящению, духовному преобразованию человека во всей целостности духа, души и тела и, как следствие, преображению социальной и природной действительности [11, c. 158].

Вместе с тем, как было отмечено выше, в отношении к природе в христианстве прослеживается некоторая двойственность. С одной стороны, не признавалась гармоничность и самодостаточность природного мира, он 
ставился на низшие ступени бытия: «О совокупности сотворенного сущего нельзя говорить как об одном существе... по двум причинам. Во-первых, потому, что мир есть собирание индивидуальных субстанций, каждая из которых может быть согласована с другими, но не образует «акциденций» или «модусов» некой единой субстанции, которую по праву следовало бы тогда назвать природой. Единственно общее всем вещам мира - бытие. Но каждая вещь имеет начало своего бытия от самого премирного Бога, а не через посредство космоса. Во-вторых, потому, что единое основание мира находится вне него, а сам мир не обладает и в принципе не может обладать основанием в себе. Он не самообоснован, не самобытен, не самоценен. Это и значит, что он сотворен из ничто» [1, с. 26]. Но, с другой стороны, мы можем привести множество примеров, когда обращение к явлениям природного мира использовалось для демонстрации красоты и величия Бога, сотворившего природу. Так, В.В. Бычков отмечает: «Идея творения мира Богом из ничего привела христиан к высокой оценке естественной красоты мира и человека, как важнейшего показателя божественного творчества» [3]. Отсюда следует, что божественную истину можно познать, воспринимая творения Бога: «Есть два пути познания: буквальное понимание слов Писания и непосредственное созерцание природного мира» [4]. Созерцание относительной красоты природы, даже омрачённой грехопадением, направляет человека к созерцанию совершенной красоты её создателя, т. е. Бога.

Христианская идеология строилась на иерархическом понимании бытия, где венцом божественного творения являлся человек, поэтому представление о его относительном совершенстве были достаточно распространены в обществе. Величественная фигура Бога дополняется фигурой человека. «В пространстве вне- и дорационального интеллекта художественно-эстетическая фигуративность..., - считает М.Н. Щербинин, - продолжает участвовать в смыслогенезе, сохраняя определённую перспективу в гармонизирующем развитии человека и его сущности» [18, с. 19]. Но представления об относительном совершенстве божественного творения распространялись и на природный мир [14].

Анализируя особенности византийской эстетики, В.В. Бычков определяет причины отношения к природе как некому подобию совершенного творения.

Во-первых, раннехристианская эстетика связывала красоту с простотой, а значит, с естественностью. Причём простота и естественность понимались не в смысле примитивизма, а в смысле природной сложности и целесообразности. О естественной простоте говорится для того, чтобы критиковать роскошь, богатство, излишества.

Во-вторых, природная красота заставляет человека задуматься о создателе этого совершенного вида, то есть о Боге: «Псевдо-Дионисий видел сущность прекрасного в «сиянии» божественной красоты, «излучения» которой образуют все виды и формы прекрасного» [7, с. 170]. Поэтому ранневизантийская эстетика трепетно относится к природным красотам.

В-третьих, за изображениями пейзажей скрыта идея, та главная духовная суть, которую автор символически 
изображает. «Образ - это важнейший способ связи и соотнесения между принципиально несоотносимыми и несвязуемыми уровнями бытия и «сверхбытия»; только в нём и посредством его возможно умонепостигаемое единство («неслитное соединение») трансцендентности и имманентности божества» [3].

Знаково-символическая функция изображений природы использовалась двумя способами. Первый строился из подобия и схожести явлений природы и возвышенных духовных переживаний. Вершины, свет, плодоносные деревья, водная гладь используются для внушения верующим благоговейных чувств, для перехода к возвышенному состоянию духа.

Большую образно-символическую значимость приписывали невзрачным и даже безобразным явлениям природного мира. Чтобы ничто не отвлекало верующих от постижения высших духовных сущностей, использовались изображения животных, растений, червей, камней. Это второй, апофатический метод символического обозначения божественной сущности. В таких изображениях должны отсутствовать привычные атрибуты красоты: гармония, мера, благородство и т.д. На этом фоне подчёркивается совершенство божественных предметов. При этом происходит своего рода реабилитация незначительных природных явлений, которые долгое время не были предметом любования, теперь и они становятся важными средствами изображения божественного совершенства.

Итак, представление о природе как об относительно совершенном творении божества характерно для религи- озного мировоззрения. Оно связано со знаково-символическим значением природных явлений. Кроме того, следует отметить, что, по мысли средневековых мыслителей, созерцание относительного совершенства в природном мире заставляет человека восхищаться творцом этого совершенства, то есть внушает мысли о Боге.

Подобные воззрения позже получили развитие в природоохранной этике, где любовь к природе и благоговение перед ней объяснялись, в том числе, её божественным происхождением. Например, философ природоохраны XIX в. Дж. Рескин считал любовь к природе религиозным чувством: «... любовь к природе, где бы она ни проявлялась, всегда была верующим и святым элементом чувства, так что хотя бы даже, при рассмотрении двух личностей, все другие обстоятельства были бы одинаковы, та, которая больше любит природу, всегда окажется более способной к вере в Бога...» (цит. по: [2, с. 94]).

\section{Совершенно в силу самоценности жизни}

Следующий аспект восприятия природы как совершенства связан с развитием естествознания, накоплением знаний о мире и разрастающимся экологическим кризисом. Суть этих взглядов можно выразить словами глубинных экологов: «Благо и процветание человеческой и иных форм жизни на земле имеет ценность в самих себе. Эти ценности не зависят от пользы нечеловеческих форм жизни для людей. Богатство и разнообразие жизненных форм вносят свою лепту в реализацию этих ценностей, и они сами по себе являются ценностями» [12, с. 56]. 
По мере роста знаний людей о природе усиливается понимание того, насколько человек зависим от природных условий своего существования. При всём своём кажущемся техническом могуществе он совершенно беспомощен без воздуха, воды, пищи и т. д. И всё это способно поддерживать жизнь лишь обладая определёнными характеристиками. В поддержании узких параметров, при которых только и возможна жизнь, задействованы столь сложные процессы, столь тонкие силы, что человек не в силах не только их контролировать, но подчас даже и понять их. «Природа, т. е. весь окружающий нас мир, наполненный живым веществом, который мы называем биосферой, имеет собственную логику развития, и ничто живое не способно, нарушая его логику, сохранить себя, ибо оно само - порождение этого мира, возникшее в силу ему присущей логики» $[10$, с. 13.]. Жизнь постепенно становится особой ценностью, её сохранение - главной задачей самых нравственных, самых достойных людей. «Как деятельное существо, человек вступает в духовные отношения к миру, проживая свою жизнь не для себя, но вместе со всей жизнью, которая его окружает, чувствуя себя единым целым с нею, соучаствуя в ней и помогая ей, насколько он может» [17, с. 28].

Биосфера организована самым наилучшим образом, процессы её саморегуляции превосходят нормативноправовое регулирование человеческих сообществ своим совершенством. Долгие века гордости человека своей исключительностью уходят в прошлое. Тому, кто привёл к угрозе уничтожения всё живое, следует вести себя скромнее.

Как только экологическая проблематика становится достоянием широкой общественности, так сразу становится ясно, что изменение критической ситуации возможно только при наличии у человека желания что-либо изменить. В этой связи на первый план выходят проблемы формирования нового, более адекватного современной ситуации мировоззрения: «Сейчас же для нас важно обратить внимание на то, что в рассмотрении экологии мы вышли за рамки науки и вторглись в сферу мировоззрения, экологизации знания и даже идеологии» [15, с. 11].

Значительный вклад в изменение потребительского отношения к природе способно сыграть эстетическое восприятие природы, которое в моменты наивысшего переживания совершенства мира поднимается до любования природой. «Искусство содержит две нерасторжимые стороны: явленность бытия и гармонию, в своём единстве выступающие только в искусстве, а не в других видах человеческой деятельности» $[13$, с. 47]. Содержательная сторона любования природой претерпевает эволюционные изменения, связанные с развитием общества. Ю. Сепанмаа считал, что для правильного эстетического восприятия природы большое значение имеют специалисты, эксперты, учителя, которые покажут ценность того, что раньше считалось диким, ужасным, плохим. Он размышлял, как научить людей видеть красоту природы. Он заключил, что необходим анализ восприятия природы, систематизация ландшафтов, исследование и конкретизация повседневного языка, отражающего ценность природы, а также широкое общественное обсуждение экологических проблем [9, с. 23-24].

Таким образом, в данной статье предложен анализ некоторых содержательных 
аспектов любования природой. Рассмотрено любование природой как восприятие её совершенства. Подобные переживания связаны с восприятием природы как совершенного творения Божества и признанием самоценности природы, сложности и совершенства процессов её саморегуляции. В других исследованиях нами рассмотрено восприятие природы как совершенной меры и гармонии и восприятие природы как чего-то более совершенного, чем человеческое общество. Проведённое исследование требует продолжения и создаст условия для формирования нового отношения к природе и решения экологических проблем.

\section{ЛИТЕРАТУРА:}

1. Ахутин А.В. Понятие «природа» в античности и в Новое время («фисис» и «натура»). М.: Наука, 1988. 208 с.

2. Борейко В.Е. Философы зоозащиты и природоохраны. Киев: Киевский экологокультурный центр, Ассоциация зоозащитных организаций Украины, 2012. (Охрана дикой природы. Вып. 64). 180 с.

3. Бычков В.В. Малая история византийской эстетики. Киев: Путь к истине, 1991. 408 с. [Электронный ресурс]. URL: http://mexalib.com/view/119002 (дата обращения: 24.08.2015).

4. Гайденко В.П. Природа в религиозном мировосприятии / [Электронный ресурс] // Вопросы философии, 1995. № 3. URL: http://filosof.historic.ru/books/ (дата обращения: 26.08.2015).

5. Ефремова Т.Ф. Новый словарь русского языка. Толково-словообразовательный. М.: Русский язык, 2000. [Электронный ресурc]. URL: http://www.efremova. info/ (дата обращения: 24.08.2015).

6. Захарова О.В. Эволюция фигуративности природных объектов // Вестник Челябинского государственного университета. Философия. Социология. Культурология. 2014. Выпуск 32. № 11. С. 67-70.
7. Лосев А.Ф., Шестаков В.П. История эстетических категорий. М.: Искусство, 1964. $376 \mathrm{c}$.

8. Льюис К.С. Любовь. [Электронный ресурс]. URL: http://www.libtxt.ru/ (дата обращения: 24.08.2015).

9. Маньковская Н.Б. Экологическая эстетика за рубежом // Философские науки, 1992. № 2. С. 16-31.

10. Моисеев Н.Н. Судьба цивилизации. Путь Разума. М.: Языки рус. культуры, 2000. 224 c.

11. Муравьёв И.Б. Эстетика евхаристии и её влияние на общество // Вестник Тюменского государственного университета. 2013. № 10. С. 154-161.

12. Наэсс А., Сессинс Д. Платформа глубинной экологии // Гуманитарный экологический журнал. Т. 2. Вып. 1. 2000. C. 56.

13. Огородников Ю.А. Специфика социального воздействия искусства на индивида / Ю.А. Огородников // Вестник Московского государственного областного университета. Серия: Философские науки, 2013. № 2. С. 45-52.

14. Подобие и подражание в средневековой культуре: Сборник статей. / Е.А. Маковецкий (отв. ред). СПб.: Философский факультет СПбГУ, 2009. 256 с.

15. Реймерс Н.Ф. Экология (теории, законы, правила, принципы и гипотезы). М.: Журнал «Россия Молодая», 1994. 367 с.

16. Словарь церковно-славянского и русского языка, составленный вторым отделением Императорской Академии Наук. В 4 т. СПб., 1847-1868. Т. 2. 475 с.

17. Швейцер А. Благоговение перед жизнью / А. Швейцер. Пер. с нем. А.А. Гусейнова. М.: Прогресс, 1992. 576 с.

18. Щербинин М.Н. Фигуративность в самопознании: эстетико-антропологический опыт // Эстетическая антропология: фигуративный аспект: коллективная монография / Под ред. М.Н. Щербинина. Тюмень: Мандр и Ка, 2014. 192 с. 